\title{
Czy można odstąpić od limfadenektomii pachowej przy przerzutach do węzła chłonnego wartowniczego?
}

\author{
Arkadiusz Jeziorski
}

\section{Axillary sentinel node metastasis: can we resign from axillary dissection?}

Motto:

„(...) Jakie znaczenie maja

Stare języki

Siejące zamęt

W nowych miejscach?"

W 1874 roku Marie Philibert Sappey opublikował atlas anatomii i fizjologii, w którym podał anatomiczne podstawy układu chłonnego człowieka [1]. Oryginalna rycina spływu chłonki z piersi znana jest wszystkim, którzy interesują się problematyką raka piersi. Z analizy rysunku wynika, że są dwie główne drogi spływu chłonki do układu chłonnego pachowego (ryc. 1).

W ostatnich latach, zwłaszcza w erze dyskusji na temat roli węzła wartowniczego (WW) w diagnostyce stanu regionalnych węzłów chłonnych w raku piersi wzrosło zainteresowanie ponownym badaniem dróg chłonnych gruczołu piersiowego [2-5]. Definicja węzła wartowniczego zaproponowana przez Cabanasa w 1970 roku brzmiała następująco: „Jest to pierwszy węzeł chłonny na drodze spływu chłonki z okolicy guza pierwotnego do regionalnego układu chłonnego". A więc definicja ta zakładała istnienie jednego węzła wartowniczego. Poczynione przez wielu autorów obserwacje anatomii układu chłonnego doprowadziły do zmiany definicji

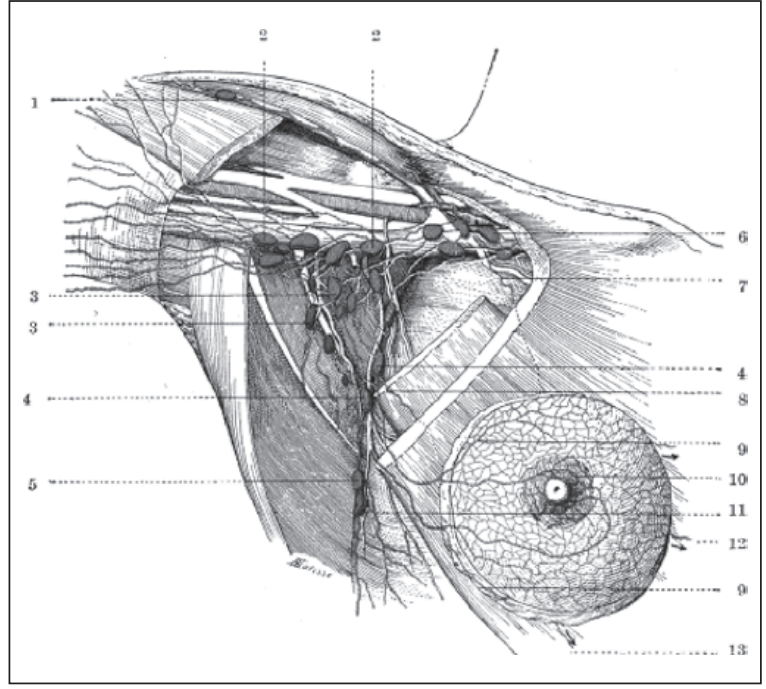

Rycina 1. Oryginalny rysunek Sappeya pokazujący dwie drogi spływu chłonki z piersi do węzłów chłonnych pachowych 


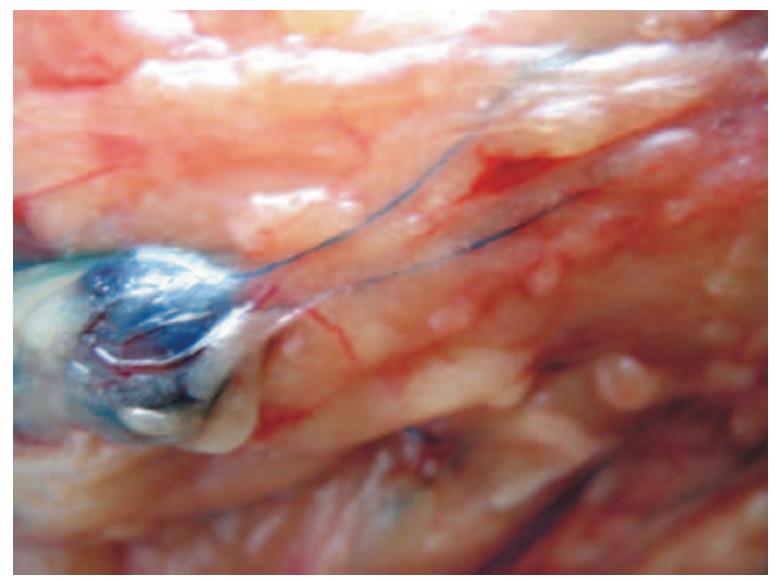

Rycina 2. Dwa naczynia chłonne prowadzą chłonkę (z barwnikiem) do jednego węzła chłonnego — badania własne (fot. A. Jeziorski)

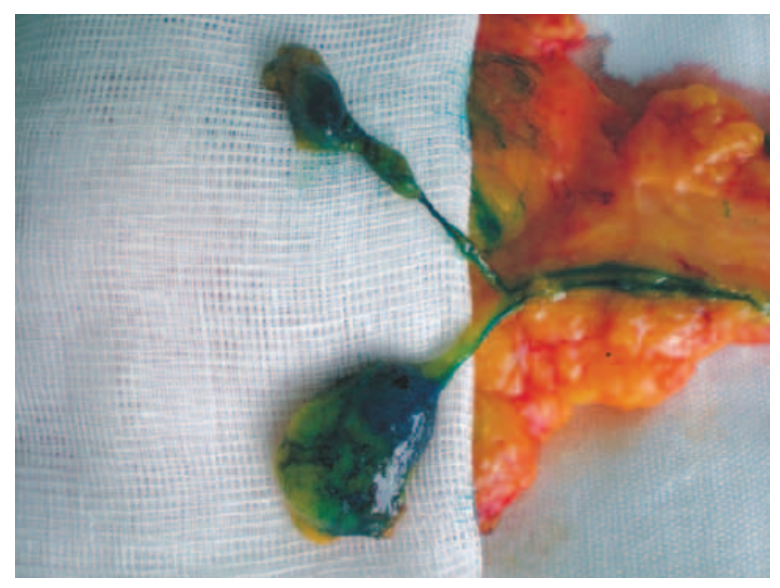

Rycina 3. Dwa naczynia chłonne prowadzą chłonkę do dwóch węzłów chłonnych wartowniczych — badania własne (fot. A. Jeziorski)

węzła wartowniczego, która aktualnie brzmi następująco: „Jest to każdy węzeł chłonny bezpośrednio połączony naczyniem chłonnym z guzem nowotworowym". Badania własne, prowadzone ex vivo [6], potwierdziły istnienie dwóch dróg prowadzących chłonkę, przy czym naczynia chłonne obu dróg mogą prowadzić do jednego węzła chłonnego (ryc. 2) lub do dwóch niezależnych węzłów (ryc. 3). Ta koncepcja zakłada, że węzłów wartowniczych może być więcej niż jeden.

Przerzuty nowotworu do węzła chłonnego mogą być w postaci izolowanych komórek, pT1i $(+)(\leq 0,2 \mathrm{~mm})$, mikroprzerzutów, pT1mi (>0,2 mm $\leq 2 \mathrm{~mm}$ ) lub makroprzerzutów (> $2 \mathrm{~mm}$ ). Dotychczasowa strategia postępowania przy stwierdzonym makroprzerzucie do WW nakazywała usunięcie regionalnego układu chłonnego w całości. Pytanie zadane w tytule niniejszej pracy jest intrygującym ciągiem dalszym dyskusji toczącej się na temat roli węzła wartowniczego w raku piersi.

\section{Jaki jest odsetek przerzutów do WW w raku piersi?}

W literaturze ten odsetek makro- i mikroprzerzutów do WW określa się na 33\% vs 12\% [7], 34,5\% vs 19,6\% [8], lub $w$ innej pracy na bazie materiału z programu AMAROS $-21,6 \%$ vs $8,5 \%$ [9]. W innych pracach podawany odsetek przerzutów nie odbiega od powyższych danych liczbowych. Mamy zatem wyobrażenie o tym, jaka jest skala problemu, o którym w tej pracy mówimy.

\section{Jaka jest ocena wartości prognostycznej mikroprzerzutów do $\mathrm{WW}$ w raku piersi?}

W holenderskim wieloośrodkowym badaniu przeprowadzono analizę opartą na 1411 chorych na raka inwazyjnego piersi w klinicznym stopniu zaawansowania T1-2N0. U wszystkich chorych zlokalizowano i zbadano węzeł wartowniczy. Następnie w okresie obserwacji dokonano podziału chorych na cztery grupy: pNo $(\mathrm{n}=922), \mathrm{pN} 1$ (mi) $(n=103), p N 1 a(n=285)$ i $p N 1 b \geq(n=101)$. Przeprowadzona analiza nie wykazała różnic w przeżyciach chorych z grup N0 i N1 (mi) (ryc. 4) [10]. Podobne wyniki osiągnęli autorzy innego badania [11].

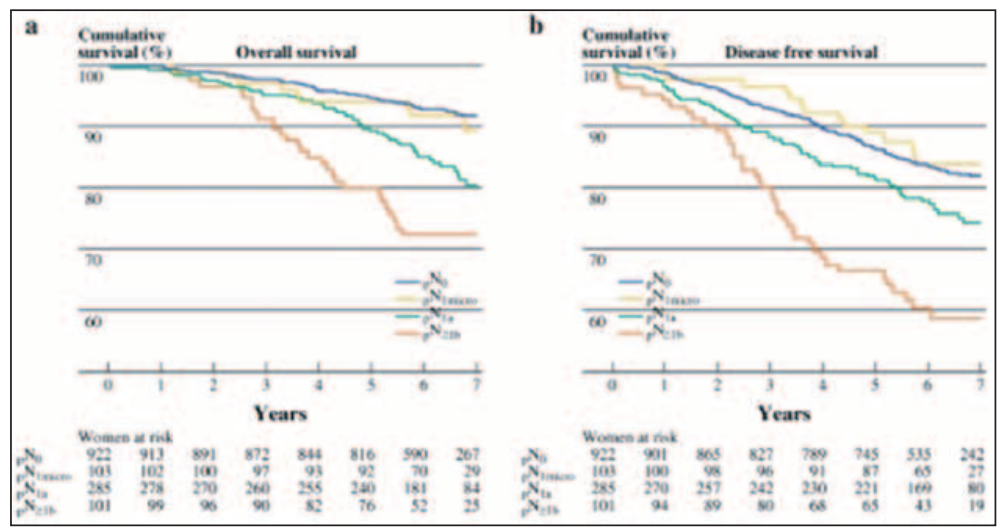

Rycina 4. Krzywe przeżycia i krzywe przeżycia do nawrotu choroby z analizy przeprowadzonej w badaniu holenderskim [10]. Zwraca uwagę brak różnic w przeżyciach chorych z cechą pNo i pN1(mi) 
Ale w pracy opublikowanej również w 2011 roku [12] wysnuto inne wnioski. W oparciu o grupę chorych z cechą pNo ( $n=123)$, pN1 (mi) $(n=27)$ oraz pN1 $(n=74)$ stwierdzono istotne różnice pomiędzy grupami pN0 i pN1(mi). Autorzy we wnioskach zwracają uwagę na te różnice, i w związku z tym na konieczność leczenia uzupełniającego u chorych z mikroprzerzutami do WW. Próbą potwierdzenia powyższych obserwacji niech będą wyniki programu MIRROR (Micrometastases and Isolated Tumor Cells, Relevant and Robust Or Rubbish) [13]. Zakwalifikowane doń chore na raka piersi (zastosowano ścisłe kryteria kwalifikacji) podzielono na następujące grupy: grupa I $(\mathrm{n}=856)$ to chore z makroprzerzutami do węzłów chłonnych, które otrzymały leczenie systemowe; grupa II ( $\mathrm{n}=856)$ - chore z mikroprzerzutami, które nie otrzymały leczenia systemowego i grupa III ( $n=995)$ obejmująca chore z mikroprzerzutami, które otrzymały leczenie systemowe. Uzyskano zaskakujące wyniki: odsetek 5-letnich przeżyć do nawrotu (DFS) w grupie II był istotnie mniejszy niż w grupie I (76,5\% vs 85,7\%; $p<0,001)$; odsetek przeżyć do nawrotu choroby w grupie II był istotnie gorszy niż w grupie III (76,5\% vs 86,2\%; p < 0,001). Wniosek mógł być tylko jeden: mikroprzerzuty w węzłach chłonnych mają znaczenie rokownicze, wobec tego wskazane jest leczenie systemowe po ich stwierdzeniu. Podobne wnioski mieli autorzy innej, podobnej pracy [14]. Przeglądając piśmiennictwo znalazłem ponad 60 prac dotyczących znaczenia rokowniczego mikroprzerzerzutów do WW w raku piersi. Część autorów uważa, że mikroprzerzuty nie mają znaczenia rokowniczego [15-17], inni zaś twierdzą, że mikroprzerzuty mają znaczenie rokownicze, i snują wnioski dotyczące konieczności uzupełniającego leczenia systemowego u tych kobiet [18-21]. Ale w żadnej z prac nie znalazłem zalecenia, że w przypadku stwierdzenia mikroprzerzutów do WW konieczna jest limfadenektomia pachowa. Niektórzy z autorów, w oparciu o doświadczenia własne, stwierdzają, że limfedenektomia w tych przypadkach powinna być uznana za overtreatment [22].

\section{Miejscowe wznowy w mikroprzerzutach do węzłów chłonnych}

To, co nas, chirurgów onkologów, mogłoby zmobilizować do wykonywania limfadenektomii w mikroprzerzutach do węzłów chłonnych, to większa liczba wznów miejscowych. W rozwiązaniu tego dylematu kluczowe jest wieloośrodkowe badanie autorów holenderskich [23]). Praca ta oparta jest o analizę 2680 kobiet: SN(-) ( $n=857)$, SN itc $(\mathrm{n}=795)$, SN (mi) ( $\mathrm{n}=1028)$. Wszystkie kobiety w podgrupach były podzielone na dwie grupy: bez dalszego leczenia oraz leczone miejscowo: chirurgicznie-limfadenektomia lub radioterapia. Wyniki świadczą o konieczności leczenia uzupełniającego w mikroprzerzutach, ale wskazują na napromienianie jako skuteczną alternatywę leczenia chirurgicznego w postaci radykalnej limfadenektomii. Inni autorzy snują podobne wnioski [24]. Do wysnucia ostatecznego wniosku służy praca zbiorcza z roku 2012 [25], w której autorzy zestawiają wyniki badań z 27 ośrodków. W pojedynczych pracach autorzy notowali występowanie niewielkiego odsetka wznów miejscowych; w większości programów badawczych wznów miejscowych nie notowano.

\section{Jaka jest wartość prognostyczna makroprzerzutów do WW w raku piersi}

Ten problem w onkologii próbuje rozwiązać Program American College of Surgeons Oncology Group (ACOSOG) Z0011 [26, 27]. Kwalifikowano chorych w zaawansowaniu raka piersi T1-2 (cT1-2N0), z przerzutami w 1-2 węzłach chłonnych wartowniczych. Do programu zakwalifikowano 891 kobiet. Po leczeniu oszczędzającym (ograniczony zabieg + napromienianie) u pacjentów z jednej grupy wykonano limfadenektomię, a u pacjentów z drugiej grupy, po ograniczonym zabiegu i radioterapii z dwóch pól tangencjalnych, zalecono obserwację. Średni czas obserwacji po zakończeniu leczenia wynosił 6,3 roku. W wynikach obserwacji stwierdzono, że nie ma różnic w czasie przeżycia oraz w przeżyciach bezobjawowych w obu grupach (ryc. 5).

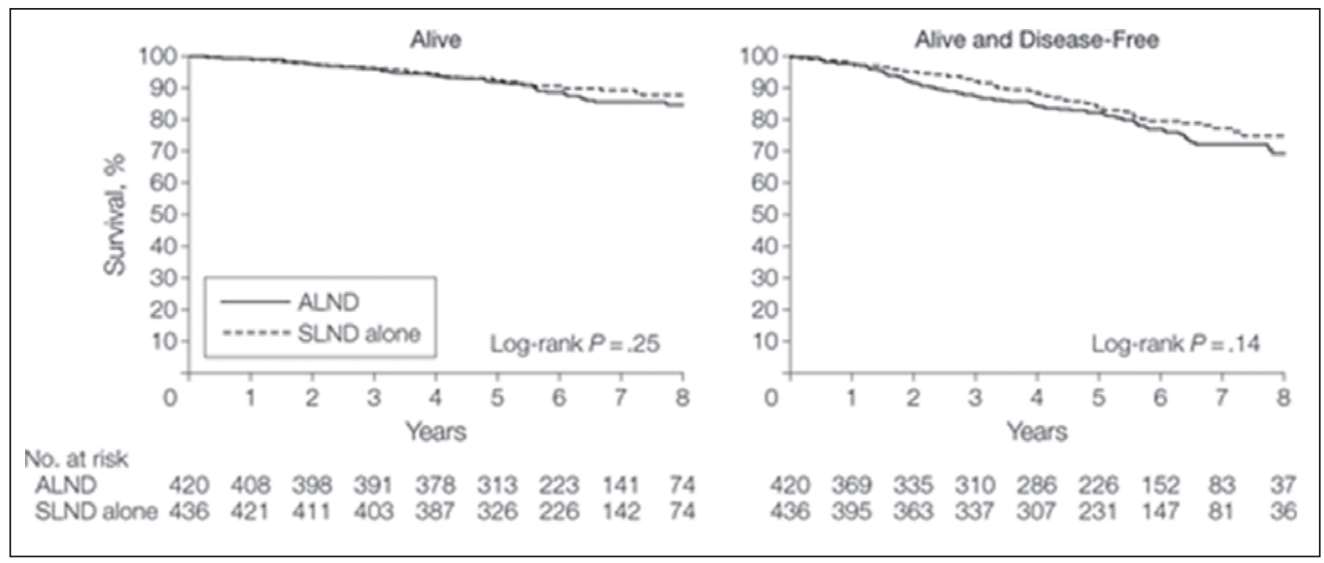

Rycina 5. Wyniki programu ACOSOG Z0011 


\section{Makroprzerzuty w węźle wartowniczym a miejscowe wznowy w dole pachowym}

Wniosek z programu (ACOSOG) Z0011 może być zweryfikowany jedynie zwiększoną liczbą wznów miejscowych w dole pachowym w makroprzrzutach w SN. I znowu należy sięgnąć do pracy zbiorczej z 2012 roku [25], w której autorzy zestawiają wyniki badań z 27 ośrodków. W pojedynczych pracach autorzy notowali występowanie niewielkiego odsetka wznów miejscowych przy makroprzerzutach w SN; w większości programów badawczych wznów miejscowych przy makroprzerzutach w SN nie notowano.

Czy zatem Program American College of Surgeons Oncology Group (ACOSOG) Z0011 wytyczy nowe szlaki, którymi pójdzie chirurgia piersi w przypadku raka tego narządu [28]? A może przyszedł już czas na zaniechanie limfadenektomii pachowej w raku piersi $[29,30]$ ? Takie pytania zadają autorzy po ukazaniu się w piśmiennictwie wniosków z Programu Z0011.

\section{Podsumowanie}

Po prawidłowo wykonanej limfadenektomii pachowej obrzęk ramienia spotykany jest w 5-39\% kobiet leczonych z powodu raka piersi. Obrzęk ramienia, niejednokrotnie o charakterze powikłania stałego, często jest powodem poważnych zaburzeń w funkcjonowaniu kończyny górnej. Wprowadzenie biopsji węzła wartowniczego w raku piersi spowodowało, że po tym zabiegu obrzęk ramienia opisywany jest zaledwie w około 2\% przypadków. Należy dążyć do minimalizowania ryzyka tego groźnego powikłania, a Program Z0011 wytycza kierunek, od którego w chirurgii piersi odwrotu być nie powinno.

\section{Prof. dr hab. med. Arkadiusz Jeziorski \\ Klinika Chirurgii Onkologicznej \\ Uniwersytet Medyczny w Łodzi \\ ul. Paderewskiego 4, 93-509 Łódź \\ e-mail:jeziorski@post.pl}

\section{Piśmiennictwo}

1. Sappey MP. Anatomie, physiologie, pathologie des vaisseaux lymphatiques considerées chez l'homme et les vertébres. Paris: A. Delahaye \& E. Lacrosnier, 1874

2. Suami H, Pan WR, Mann GB i wsp. The lymphatic anatomy of the breast and its implications for sentinel lymph node biopsy: a human cadaver study. Ann Surg Oncol 2008; 15: 863-871.

3. van der Ploeg IM, Kroon BB, Antonini N i wsp. Axillary and extra-axillary lymph node recurrences after a tumor-negative sentinel node biopsy for breast cancer using intralesional tracer administration. Ann Surg Oncol 2008; 15: 1025-1031.

4. Veronesi U, Marubini E, Mariani L i wsp. The dissection of internal mammary nodes does not improve the survival of breast cancer patients, 30-year results of a randomised trial. Eur J Cancer 1999; 35: 1320-1325.

5. Heuts EM, van der Ent FW, von Meyenfeldt MF i wsp. Internal mammary lymph drainage and sentinel node biopsy in breast cancer - a study on 1008 patients. Eur J Surg Oncol 2009; 35: 252-257.

6. Jeziorski A., Piekarski J, Nejc D i wsp. Ex-vivo search for sentinel node in post-mastectomy specimens. Should we use a transverse incision for mastectomy? Ann Surg Oncol 2007; 14: 3111-3116.
7. Viehl CT, Langer I, Guller U i wsp. Prognostic impact and therapeutic implications of sentinel lymph node micro-metastases in early-stage breast cancer patients. J Surg Oncol 2011; 103: 531-533.

8. lannace C, Di Libero L, Lepore M i wsp. Prognostic and curative value of sentinel node in breast cancer. A 377 patients experience. Ann Ital Chir 2010; 81: 103-111.

9. Straver ME, Meijnen P, van Tienhoven G i wsp. Sentinel node identification rate and nodal involvement in the EORTC 10981-22023 AMAROS trial. Ann Surg Oncol 2010; 17: 1854-1861.

10. Gobardhan PD, Elias SG, Madsen EV i wsp. Prognostic value of lymph node micrometastases in breast cancer: a multicenter cohort study. Ann Surg Oncol 2011; 18: 1657-1664.

11. Maaskant-Braat AJ, van de Poll-Franse LV, Voogd AC i wsp. Sentine node micrometastases in breast cancer do not affect prognosis: a population-based study. Breast Cancer Res Treat 2011; 127: 195-203. doi: 10.1007/s10549-010-1086-6.

12. Viehl CT, Langer I, Guller U i wsp. Prognostic impact and therapeutic implications of sentinel lymph node micro-metastases in early-stage breast cancer patients. J Surg Oncol 2011; 103: 531-533.

13. de Boer $M$, van Deurzen CHM, van Dijck JAAM i wsp. The prognostic role of micrometastases and isolated tumor cells in axillary lymph nodes in early stage breast cancer: the Dutch MIRROR study. N Eng/J Med 2009; 361: 653-663.

14. de Boer M, van Deurzen CHM, van Dijck JAAM i wsp. Micrometastases or isolated tumor cells and the outcome of breast cancer. NEngl J Med 2009; 361: 653-663.

15. Gobardhan PD, Elias SG, Madsen EV i wsp. Prognostic value of lymph node micrometastases in breast cancer: a multicenter cohort study. Ann Surg Oncol 2011; 18: 1657-1664.

16. Maaskant-Braat AJ, Adriana J, van de Poll-Franse. Sentinel node micrometastases in breast cancer do not affect the prognosis: a population based study. Breast Cancer Res Treat 2010; 127: 195-203.

17. Cortesi L, Proietto M , Cirilli C i wsp. Prognosis and treatment of micrometastatic breast cancer sentinel lymph node: a population based study. J Surg Oncol 2012; 106: 399-405.

18. De Boer M, van Dijck JA, Bult P i wsp. Breast cancer prognosis and occult lymph node metastases, isolated tumour cells and micrometastases. J Natl Cancer Inst 2010; 102: 410-425.

19. Salhab M, Patani N, Mokbel K i wsp. Sentinel lymph node micrometastases in human breast cancer: an update. Surgical Oncology 2011; 20: e195-206.

20. Rovera F, Frattini F, Chiappa C i wsp. The role of micrometastatic disease in sentinel lymph node in breast cancer. Breast Journal 2010; 16 Suppl 1:S26-28.

21. Masci G, Di Tomasso L, Del Prato I i wsp. Sinusal localization of nodal micrometastases is a prognostic factor in breast cancer. Ann Oncol 2010; 21: 1228-1232.

22. Attene F, Paliogiannis $P$, Scognamillo F i wsp. Axillary lymph node dissection in patients with breast cancer and sentinel lymph node micrometastasis or isolated tumor cells: is it necessary? Tumori 2012; 98: 320-323.

23. Pepels MJ, de Boer M, Bult P i wsp. Regional recurrence in breast cancer patients with sentinel node micrometastases and isolated tumor cells. Ann Surg 2012; 255: 116-121.

24. Cortesi L, Proietto M, Cirilli C i wsp. Prognosis and treatment of micrometastatic breast cancer sentinel lymph node: a population-based study. J Surg Oncol 2012; 106: 399-405.

25. Francissen CM, Dings PJ, van Dalen T i wsp. Axillary recurrence after a tumor-positive sentinel lymph node biopsy without axillary treatment: a review of the literature. Ann Surg Oncol 2012; 19: 4140-4149.

26. Giuliano AE, Hunt KK, Ballman KV i wsp. Axillary dissection vs no axillary dissection in women with invasive breast cancer and sentinel node metastasis. A randomized clinical trial. JAMA 2011; 305: 569-575.

27. Caudle AS, Hunt KK, Tucker SL i wsp. American College of Surgeons Oncology Group (ACOSOG) Z0011: Impact on Surgeon Practice Patterns. Ann Surg Oncol 2012; 19: 3144-3151.

28. Guth U, Myrick ME, ViehI C T i wsp. The post ACOSOG Z0011 era: does our new understanding of breast cancer really change clinical practice? Eur J Surg Oncol 2012; 38: 645-650.

29. Dominici L, Golshan M. Can axillary lymph node dissection be omitted in patients with breast cancer and positive sentinel nodes? Minerva Chir 2010; 65: 547-554.

30. Nakamura S. Axillary lymph node dissection in sentinel node positive breast cancer: is it necessary? Curr Opin Obstet Gynecol 2013; Feb 19. [Epub ahead of print]. 